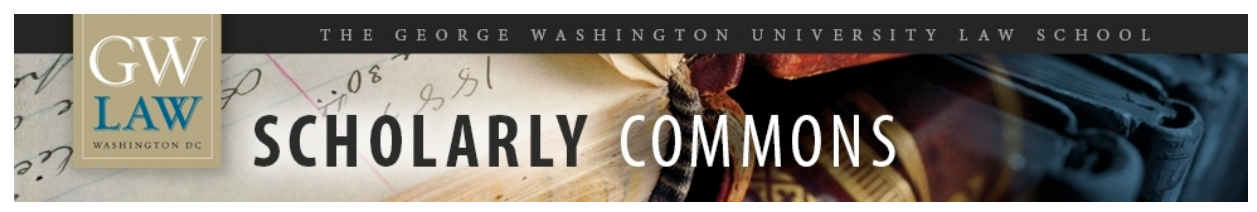

\title{
Prior Consistent Statements: The Dangers of Misinterpreting Recently Amended Fre 801(D)(1)(B)*
}

\author{
Laird Kirkpatrick \\ George Washington University Law School, Ikirkpatrick@law.gwu.edu \\ Christopher B. Mueller
}

Follow this and additional works at: https://scholarship.law.gwu.edu/faculty_publications

Part of the Law Commons

\section{Recommended Citation}

Kirkpatrick, Laird C., Prior Consistent Statements: The Dangers of Misinterpreting Recently Amended Fre 801(D)(1)(B)* (2016). 24 Trial Evidence 12 2016; GWU Law School Public Law Research Paper No. 2016-40; GWU Legal Studies Research Paper No. 2016-40. Available at SSRN: http://ssrn.com/ abstract $=2836114$

This Article is brought to you for free and open access by the Faculty Scholarship at Scholarly Commons. It has been accepted for inclusion in GW Law Faculty Publications \& Other Works by an authorized administrator of Scholarly Commons. For more information, please contact spagel@law.gwu.edu. 
Prior Consistent Statements: The Dangers of Misinterpreting Recently Amended FRE 801(d)(1)(B)*

Federal Rule of Evidence 801(d)(1)(B) has long provided that prior statements consistent with the testimony of a witness who is subject to crossexamination may be introduced and used as substantive evidence when offered "to rebut an express or implied charge that the declarant recently fabricated it or acted from a recent improper influence or motive in so testifying." At the end of 2014, the rule was amended also to allow prior consistent statements to be introduced as substantive evidence when offered "to rehabilitate the declarant's credibility as a witness when attacked on another ground."

When the Federal Judicial Center circulated the proposed amendment to federal district judges for comment, they overwhelmingly predicted that the amendment would lead to a significant expansion in attempts to introduce prior consistent statements at trial, even though this was not the purpose of the amendment. See FJC Survey, http://www.fjc.gov/public/pdf.nsf/lookup/rule801d1b.pdf/\$file/rule801d1b.pdf To respond to this concern, the Advisory Committee added a Note to the amended rule specifically stating: "This amendment does not change the traditional and wellaccepted limits on bringing prior consistent statements before the factfinder for credibility purposes. It does not allow impermissible bolstering of a witness. ... The amendment does not make any consistent statement admissible that was not admissible previously - the only difference is that prior consistent statements otherwise admissible for rehabilitation are now admissible substantively as well." (emphasis added)

Nonetheless, a significant danger remains that the amended rule will be misunderstood by lawyers and judges and applied in an overly expansive fashion. This is not only because Advisory Committee Notes are sometimes overlooked or ignored in the heat of trial, but also because the amended rule does not itself specify when prior consistent statements may be used to rehabilitate witnesses. Instead it adopts federal common law on the issue of when prior consistent statements are admissible for rehabilitation and merely provides that if a prior consistent statement is admissible for rehabilitation, it is also admissible for its truth. Thus, to apply the amendment properly attorneys and courts must research and consider law outside FRE 801(d)(1)(B).

This point would have been made clearer if the drafters had added just three words to the amended language, so that it read "when otherwise admissible to rehabilitate the declarant's credibility as a witness when attacked on another ground." As a leading academic commentator has noted, the absence of those words means that lawyers and judges may "be lulled into thinking that the rehabilitation requirement is automatically satisfied for any prior consistent statement falling within the amended rule" and misinterpret the rule "to bless and automatically 
admit any prior consistent statement offered to repair an impeaching attack." Liesa Richter, Seeking Consistency for Prior Consistent Statements, 46 Conn. L. Rev. 937, 983 (2015).

Even those lawyers and judges who recognize that proper application of FRE 801(d)(1)(B) requires resort to law outside the rule itself face a challenge, because there is no other provision in the Federal Rules of Evidence addressing rehabilitation by use of prior consistent statements. Instead they must look to the federal common law. The Advisory Committee's Note says the amended rule is subject to the "traditional and well-accepted limits" on admitting prior consistent statements for rehabilitation, but it does not detail what they are.

Perhaps the most fundamental common law limitation on the use of prior consistent statements is that they cannot be introduced to rehabilitate a witness after every kind of impeaching attack, despite the language in the rule about using prior consistent statements to rehabilitate after the witness has been attacked "on another ground." For example, impeachment by evidence of prior convictions, prior bad acts, bad character for truthfulness, and failure of perception (such as bad eyesight) do not ordinarily provide a basis to rehabilitate a witness by introducing a prior consistent statement. See Mueller \& Kirkpatrick, 4 Federal Evidence $§ \S 8.38$, 8.39 (4th ed. 2013).

The only two types of attack mentioned in the Advisory Committee Note as potentially being covered by the amended language are a charge of "faulty memory" and evidence of "an inconsistency in the witness's testimony." Certainly an attack on a witness's memory should trigger the right to rehabilitate the witness by evidence of a consistent statement made at or near the time of the event about which she is testifying. But even here caution is in order. A charge of faulty memory does not open the door to all prior consistent statements. For example, if a witness is challenged about her ability to remember the details of an accident she observed four years ago, it does not rehabilitate her to bring out a consistent statement she made at a deposition two weeks prior to her current testimony.

Similarly it has never been the rule that impeachment by prior inconsistent statement automatically opens the door to evidence of prior consistent statements. See Mueller \& Kirkpatrick, id. at \$6.102. Proving prior consistent statements does not remove the sting of vacillation raised by the inconsistent statements because the inconstancy remains. Only in certain limited circumstances does a prior consistent statement rehabilitate a witness who has been impeached with a prior inconsistent statement. For example, a prior consistent statement may rehabilitate a witness by clarifying or giving context to the alleged prior inconsistent statement or by supporting a denial that the prior inconsistent statement was ever made. And of course sometimes impeachment by a prior inconsistent statement will suggest that the direct testimony of the witness is a recent fabrication or a product of improper influence or motive, which would trigger the opportunity to rehabilitate the witness with a prior consistent statement under FRE 801(d)(1)(B)(i). 
If federal judges are correct that adoption of this amendment will lead to more frequent attempts to offer prior consistent statements, another danger presents itself. Sometimes attorneys offer prior consistent statement containing significant details that were not included in the trial testimony of the declarant. An important and well-established common law limitation on the use of prior consistent statements, particularly since they are generally not made under oath, is that they cannot go beyond what the witness testified to at trial. See Mueller \& Kirkpatrick, id. at $\S 8: 38$. This is another restriction that will require careful judicial policing in those cases where prior consistent statements are properly admissible under the amended rule.

Another possible misinterpretation of the amended rule would be to view it as eliminating the premotive requirement established by Tome v. United States, 513 U.S. 150 (1995). In Tome the Supreme Court held that a prior consistent statement offered to rehabilitate a witness impeached by an alleged motive to fabricate, and hence admissible as substantive evidence under FRE 801(d)(1)(B), must have been made prior to the time that motive arose.

The primary goal of the earliest advocates for amending the rule was to overturn Tome and reject the premotive requirement. See Bullock and Gardner, Prior Consistent Statements and the Premotive Rule, 24 Fla. St. U. L. Rev. 509 (1997) (urging that FRE 801(d)(1)(B) be amended to allow post-motive statements to be admitted as substantive evidence, thereby overturning Tome). Based on its earlier drafts and commentary, the Advisory Committee originally appeared to be headed in this direction. But the Committee apparently had second thoughts about using a proposed rule amendment to overturn a Supreme Court decision. Thus the amended rule was submitted to the Supreme Court and promulgated with an Advisory Committee Note that specifically states: "The amendment retains the requirement set forth in Tome v. United States . . that under Rule 801(d)(1)(B) a consistent statement offered to rebut a charge of recent fabrication or improper influence or motive must have been made before the alleged fabrication or improper influence or motive arose."

The question remains whether a post-motive statement, even if not admissible under FRE 801(d)(1)(B) as substantive evidence, can nonetheless be received solely for rehabilitation, as a few courts have permitted. Such a strategy would seem inconsistent with both Tome and the amended rule. In adopting the premotive requirement, the Tome Court was stating a common law relevancy principle as well as interpreting a hearsay rule. It is extremely unlikely that the Tome Court would have approved the use of the post-motive statements offered in that case if only a limiting instruction had been given telling the jury they were to be considered merely for rehabilitation.

To allow post-motive statements for rehabilitation would also go against both the letter and the spirit of the amended rule. The amended rule states that any prior consistent statement properly admitted for rehabilitation is now substantive 
evidence. To allow a post-motive statement for rehabilitation only, a court would have to block the automatic effect of FRE 801(d)(1)(B) by giving a limiting instruction. But in doing so the court would be returning to a two-tier system where some prior consistent statements come in as substantive evidence and others only for rehabilitation. The very purpose of the amendment was to abolish this two-tier system and eliminate the need for courts to give limiting instructions when prior consistent statements are properly received for rehabilitation purposes.

Litigators and judges would be well advised to consult both common law rehabilitation principles as well as Tome when seeking to interpret and apply the recently-amended language of FRE 801(d)(1)(B).

*By Professor Laird Kirkpatrick, George Washington University Law School, and Professor Christopher B. Mueller, University of Colorado School of Law 